\title{
DIFFERENCES OF INDIRECT MAR TEST IN THE UNEXPLAINED INFERTILE AND FERTILE COUPLES
}

\author{
Nur Hafiz Ramadhona, Aucky Hinting, Hamdani Lunardhi \\ Department of Medical Biology, Faculty of Medicine, Universitas Airlangga, Dr. Soetomo Hospital, Surabaya, \\ Indonesia
}

\begin{abstract}
Infertility is the inability of a partner to get pregnant after regular sexual intercourse without contraception for 12 months. Based on the cause, male infertility is caused by genetic, hormonal, infectious, sexual, and unexplained infertility. However, many infertile couples are classified into unexplained infertility without an antisperm antibody (ASA) immunological examination. This study aimed to prove that couples classified as unexplained infertility can be caused by ASA wives. This was an observational study with a cross sectional study design. The sample consisted of 2 groups, in which the first group consisted of 36 fertile couples and the second group consisted of 35 unexplained infertility couples. All samples were carried out indirect MAR test to obtain the ASA value of the wife. If the wife's ASA value was $>40 \%$, the ASA results were positive. Conversely, if the ASA value was $<40 \%$, the ASA results were negative. From these 2 groups, there was a statistically significant difference ( $p<0.0001)$ that the wife's ASA value in the unexplained infertility group was significantly higher than that in the fertile group. This study concluded that the positive ASA results from the indirect MAR test were significantly found in the unexplained infertility sample.
\end{abstract}

Keywords: ASA; antisperm antibodies; indirect MAR Test

\section{ABSTRAK}

Infertilitas adalah ketidakmampuan pasangan untuk hamil setelah berhubungan seksual secara rutin tanpa kontrasepsi selama 12 bulan. Berdasarkan penyebabnya, infertilitas pria maupaun wanita disebabkan oleh genetik, hormonal, infeksi, seksual, dan unexplained infertility atau infertilitas yang tidak terjelaskan. Namun, banyak sekali pasangan infertil yang digolongkan ke dalam unexplained infertility tanpa dilakukan pemeriksaan imunologi antibody antisperma (ASA). Penelitian ini bertujuan untuk membuktikan bahwa pasangan yang digolongkan sebagai unexplained infertility dapat disebabkan oleh ASA istri. Penelitian ini merupakan studi observasi dengan rancangan penelitian cross sectional. Sampel terdiri dari 2 kelompok, di mana kelompok pertama merupakan pasangan fertil berjumlah 36 orang dan kelompok kedua merupakan pasangan unexplained infertility berjumlah 35 orang. Semua sampel dilakukan pemeriksaan indirect MAR Test untuk mendapatkan nilai ASA istri. Bila nilai ASA istri >40\%, maka hasil ASA positif. Sedangkan, bila nilai ASA < 40\%, maka hasil ASA negatif. Dari 2 kelompok tersebut, didapatkan perbedaan bermakna secara statistik $(p<0,0001)$ bahwa nilai ASA istri pada kelompok unexplained infertility lebih tinggi dari pada kelompok fertil secara bermakna. Penelitian ini menyimpulkan bahwa hasil ASA positif dari pemeriksaan indirect MAR Test secara signifikan terdapat pada sampel unexplained infertility.

Kata kunci: ASA; antibodi antisperm; indirect MAR Test

Correspondence: Nur Hafiz Ramadhona, Department of Medical Biology, Faculty of Medicine, Universitas Airlangga, Jalan Prof. dr. Moestopo 47, Surabaya 60131, Indonesia. E-mail: nramadhona@gmail.com

pISSN:2355-8393 • eISSN: 2599-056x • doi: 10.20473/fmi.v56i1.18442

- Fol Med Indones. 2020;56:1-3 • Received 31 Jan $2017 \bullet$ Accepted 20 Jul 2017

- Open access under CC-BY-NC-SA license • Available at https://e-journal.unair.ac.id/FMI/

\section{INTRODUCTION}

Infertility is the inability of a partner to produce a pregnancy after having a regular relationship without contraception for 1 year. The causes of infertility are genetic, hormonal, infectious, sexual, and unexplained infertility. According to the American Society for Reproductive Medicine (ASRM), to state unexplained infertility, anamnesia must be performed to determine cryptorchidiem history, medical and surgical history, previous history of paternity, sexual dysfunction, use of drugs, smoking, alcohol, drugs, and semen examination, physical examination to see the condition of the testes such as varicocele and the state of the vas deferens, while the wife is evaluated for ovulation of the wife, hysterosalpingogram (Mahdi et al 2011). Anti-Sperm 
Antibody (ASA) is an antibody that interferes with sperm work. 10-20\% of reproductive age cases of infertility are classified as unexplained infertility, while 9-36\% of these cases are thought to be caused by ASA. The role of wife ASA can cause partner infertility, but research on wife ASA is still very little. Whereas we know that the role of ASA wife is quite large in inhibiting sperm work, so that pregnancy is difficult (Mahdi et al 2011). The wife's ASA study using MAR Test is very rare, even though indirect MAR tests are relatively cheap, fast, and accurate. ASA is present in blood, sperm, follicular fluid and cervical secretions. ASA can inhibit sperm movement, the process of capacitation, fertilization, and embryo implantation (Bohring et al 2003). The high value of a wife's ASA is influenced by genetics, diet, sperm characteristics, and some diseases. ASA production is closely related to sperm antigen stimulation. However, many antigens on the surface of sperm coincide with somatic cells (Mathur et al 1981). Under normal circumstances, ASA wives are within normal limits, but if the ASA value increases, it will inhibit sperm work. ASA can affect the penetration of sperm in the cervical mucus with immobilization and vibrational phenomena in sperm in cervical mucus (Lombardo et al 2001). Normally, there is an ASA in the body of a woman who has been exposed to sperm within reasonable limits $(<40 \%)$ (Hinting et al 1988). Low ASA can increase uterine reception for embryo implantation, and is beneficial in the Embryo Transfer process in IVF (Nakagawa et al 1999).

\section{MATERIALS AND METHODS}

This was an observational study to assess the ASA comparison of wives from unexplained infertility and fertile couples by examining indirect MAR Test. The population of this study was female patients diagnosed with unexplained infertility and fertile female patients who visited RSIA Sayyidah, Jakarta. The study was conducted from September to December 2016. The sample consisted of 35 unexplained infertility couples and 36 fertile couples who met the inclusion and exclusion criteria. The inclusion criteria of an unexplained infertility partner were a married couple aged 25-45 years, having sexual intercourse regularly without contraception for at least a year, the wife had never been pregnant and had been diagnosed unexplained before. Inclusion criteria for fertile couples were married couples aged 25-45 years, women who are pregnant or have been pregnant in less than 2 years ago from the results of a normal pregnancy. The exclusion criteria for unexplained infertility couples are couples with positive TORCH, wives having menstrual cycle disorders, PCOS, endometriosis, wives having dead-end tubes, husband's sperm analysis values declared abnormal, husband's sex physical examination not normal, husband having surgery in the area around the pelvis, history of cryptorchidism and sexual dysfunction. Exclusion criteria for fertile couples are wives who have a history of fever in less than 3 months ago, wives consume immunosuppressants within the last 3 weeks, wives suffer from diseases that cause decreased immunity. The ASA examination of the wife was carried out using the indirect MAR Test according to WHO 1999 recommendations. The ASA results obtained were in the form of quantitative data in the form of percentages. The variable tested is the value of the wife ASA with a numerical measurement scale (ratio). The types of hypotheses are comparative and the groups tested are two groups between independent samples using the Mann-Whitney analysis because the data are not normally distributed. Ethical feasibility was obtained from the ethics commission of the Faculty of Medicine, Universitas Airlangga, Surabaya.

\section{RESULTS}

Based on the normality test, the data obtained were not normally distributed, so to assess the different tests between the two groups using Mann-Whitney Test. The following are the results of the indirect MAR test in the two groups using the Mann-Whitney Test. The results showed that the ASA values of the wives of fertile unexplained infertility couples showed a statistically significant difference $(\mathrm{p}<0.0001)$.

Table 1. Results of indirect MAR test Test in both groups using Mann-Whitney Test

\begin{tabular}{lccc}
\hline Groups & $\mathrm{n}$ & Mean rank & P value (Mann- Whitney) \\
\hline Fertile & 36 & $19.11^{\mathrm{a}}$ & $<0.0001$ \\
Unexplained Infertile & 35 & $53.37^{\mathrm{b}}$ & \\
\hline \multicolumn{4}{l}{ Note: Different superscripts show significant differences }
\end{tabular}




\section{DISCUSSION}

Sperm is a hidden antigen by a man's body. In women, ASA is in blood, follicular fluid, and cervical lenders. Under normal circumstances, there is ASA in a woman's body under normal conditions $(<40 \%)$. So far, many infertile patients have been diagnosed as unexplained infertility without prior immunological examination due to technological limitations. However, with indirect MAR test, ASA examination can be done relatively cheaply, easily and accurately. Low ASA can increase the reception of uterine for embryo implantation, and is beneficial in the process of embryo transfer in IVF (Nakagawa et al 1999). In the above study, the mean value of the indirect MAR test from the unexplained infertility group was $53.8 \%$ while in the fertile group it was $25.1 \%$. In this study, the maximum and minimum values of the MAR Test from the unexplained infertility group were $38 \%-72 \%$, while those in the fertile group were $11 \%-47 \%$.

Differences above were stated statistically significant. This is in accordance with the research conducted by Mahdi et al (2011), that there was ASA which increased significantly in infertile women. ASA can stick to the sperm's tail or sperm head. ASA that attaches to the sperm's tail will reduce the number of sperm motility, while the ASA attached to the sperm head will affect the acrosome reaction in the pellucida zone. ASA production can be triggered by chronic infections such as Chlamydia trachomatis, vasectomy and vasovasostomy, and exposure to heavy metals such as mercury (Lee et al 1987, Silber \& Grotjan 2004). In cervical lenders, ASA can cause severe infertility, because ASA can affect sperm penetration in cervical lenders by imonilization and vibration phenomena in sperm (Shi et al 2007).

\section{CONCLUSION}

Increased wife ASA values were found in unexplained infertility couples compared to fertile couples.

\section{REFERENCES}

Bohring C, Krause W (2003). Immune infertility: towards a better understanding of sperm (auto)immunity. The value of proteomic analysis. Hum. Reprod 18, 915-924

Hinting A, Vermeulen L, Comhair F (1988). The indirect mixed antglobulin reaction tets using a commercially available kit for the detection of antisperm antibodies in serum. Feril Steril 49, 1039-44

Lee HY, Kim JQ, Kim SI (1987). Sperm auto-immunity associated with vasectomy, vasovasostomy and epididymovasostomy in Korean males. Clin.Reprod. Fertil. 5, 347-357

Lombardo F, Gandini L, Dondero F, Lenzi A (2001). Immunology and immunopathology of the male genital tract. Hum. Reprod. Update 7, 450-456

Mahdi BM, Salih WH, Caitano AE, Kadhum BM, Ibrahin DS (2011). Frequency of antisperm in infertile women. J Reprod Infertil 12, 261-265

Mathur S, Goust JM, Williamson HO, Fudenberg HH (1981). Cross-reactivity of sperm and T lymphocyte antigens. Am. J. Reprod. Immunol. 1, 113-118

Nakagawa K, Yamano S, Kamada M, Hinokio K, Maegawa M, Aono T (1999). Quality of embryo does not affect the implantation rate of IVF-ET in infertile women with antisperm antibody. Fertil.Steril 72, 1055-1060

Shi J, Yang Z, Wang M (2007). Screening of an antigen target for immunocontraceptives from cross-reactive antigens between human sperm and Ureaplasmaurealyticum. Infect. Immun. 75, 20042011

Silber SJ, Grotjan HE (2004). Microscopic vasectomy reversal 30 years later: A summary of 4010 cases by the same surgeon. J. Androl. 25, 845-859 